\title{
MUSIC IN ITS RELATION TO THE MIND.*
}

\author{
BY G. ALDER BLCMER, M. D.,
} Utica, N. Y.

The important part played by the nerrous srstem in all diseases to which human flesh is heir is so well recognized and appreciated as to make natural and equally important the attempt on the part of man, and especially the medical man, to reach and operate upon that nervous system for the relief and cure of disease. It is oftentimes through the medium of the senses alone that medical science attempts to produce its effects in brain and nervous diseases. Adrantage is taken in therapentics of the sense of taste, and with equal frequency that of touch is called into play in the healing art through the instrumentality of the skin, its rich nervous supply affording a ready means of access to the central system. It is only necessary to mention, in this connection, electricity in its manifold applications, and the salutary influence of heat and cold in sundry affections. Again, mental or nerrous excitement may be provokẹd or calmed through the sense of smell by means of ethereal substances; and but a few years have elapsed since the public, fairly crazed with what seemed to be the greatest discovery of the age, sought self-medication by appealing to the sense of sight with the assistance of colored glass. It was then alleged, with some semblance of credibility, that even diseases of the brain could be cured by subjecting the patient to the healing influence of the sun's rays as transmitted through glass of various hues, and what was called, in high sounding phrase, "the photochromatic treatment of insanity" gained several funatical followers.

It would seem, however, that the sense of hearing has not been appreciated by physicians, in the treatment of disease in due proportion to its availability as a factor in treatment, for the influence of sound upon the nervous system surely offers no barren field to the investigator in this direction.

* This paper was read before a popular audience at the Conservatory of Music, and subsequently read at the annual meeting of the Association of Medical Superintendents of American Institutions for the Insane, held at Niagara Falls, 1890. It is published here by request. 
" Give me some Music,

Now, good Casiario, but that piece of song,

Thut old and antique song we heard last night;

Nethought it did relieve iny passion much."

But susceptibility to auditory impressions as received and collated in the brain-in other words, susceptibility to the influence of music-varies greatly. It is well known that there are those who are hopelessly without taste for music, and who may never acquire it. In these cases there would seem to be a congenital defect in the brain centres devoted to music, if such there be.

"Speech," salys Broussalis, "is heard and repeated of all men who are not deprived of their auditory sense, because they are all endowed with cerebral organization fit to procure for them distinct ideas upon the subject. Music, when viewed as a mere noise, is also heard by everyone, but it furnishes ideas sufficiently clear to be reproduced, to those only whose individual frames are organized in a manner adiupted to this kind of sensation."

In justice to those who are not keenly.sensitive to musical impressions-l might almost say in self-defence-I mention these physiological facts in passing to refute the opinion, prevalent especially among musicians themselves, that the want of the musical faculty, or of the nusieal taste, is an evidence of mental or moral inferiority.

We are too apt to take it for grinted that in all matters philosophical Shakspere's ipse dixil constituted the last word, and perhaps the bard has done much to perpetuate this heresy abont music by his lines:

"The man that hath not music in himself, Nor is not mored with concord of sweet sounds,

Is fit for treasons, st rutugems and spoils;

The motions of his spirit are dull as night,

And his affections dark as Erebus-

Let no such man be trusted."

Ind Beattie's picture of such a man is yet more doleful:

"Is there a heart that music cannot melt?

Alas! how is that rugged heart forlorn;

Is there who ne'er those mystic transports felt

Of solitude and melancholy born!

He needs not now the muse; be is her scorn.

The sophist's rope of cobweb he shall twine,

Mope o'er the schoolman's page; or mourn,

And delve for life in mammon's dirty mine,

Sneak with the scoundrel fox, or grunt with glutton swine."

Vor. XLVIII-No. III-D. 
The ear may be perfect in every other respect and yet be deaf to certain notes, just as the eye may be perfect in every other way and yet be color blind.

There are ears that seem to have no defect in the general capacity: of receiving sound or in the perception of musical tones, but are insensible to very acute sounds. This insensibility commences when the vibrations have attained a certain degree of rapidity beyond which all sounds are inaudible. Thus some persons cannot hear the chirp of the grasshopper; others the cry of the bat; and a case is on record in which the note of the sparrow was inaudible. I know a lady in Utica with whom, under ordinary circumstances, it is very difficult for me to carry on a conversation even at the top of my lungs, but let me talk to her while rattling over the cobblestone pavements of that city in a carriage, when the noise is so deafening sometimes as to make my voice almost inaudible to my own ears, and she hears without any difficulty.

As in analogous cuse I find recorded that of a shoemaker who had to strike continuously upon his stone while talking to his son, who was affected with deafness; and of a man-surely a very devoted husband-who had to keep a servant in the room beating a drum to enable his wife to hear his conversation.

We read in Boswell's Life of Johnson the following conversation as showing how insusceptible the great philosopher was to musical impressions:

"In the evening our gentleman farmer and two others entertained themselves and the company with a great number of tunes on the fiddle. Johnson desired to have 'Let ambition fire thy mind' played over again, and appeared to give a patient attention to it; though he owned to me that he was very insensible to the power of music. I (Boswell) told him that it affected me to such a degree as often to agitate my nerves painfully, producmg in my mind alternate sensations of pathetic dejection, so that I was seady to shed tears; and of daring resolution, so that $I$ was inclined to rush into the thickest part of the battle. Sir, said he (Johnson) I should never hear it, if it made me such a fool."

With this comforting apology for those in my audience who, though they may not be very musical, are yet great men and great women, I proceed to speak of a few of the applications of music in every day life. 
According to its quality music has an animating or lulling effect upon the invalid listener. It gives courage to the patient and fills the convalescent with joyous hope of speedy restoration, and all physicians can attest by actual experience the truth of the common observation that a sick man who sings is on the high roal to recovery. More frequent still is the demonstration of music's spells in the nursery. Everybody knows-blessed knowledge too to those of us who have been married but a few years-how easily a crying babe may be quieted by a nurses singing and lulled to sleep. Even a rhythmical tattoo with little sound will sometimes produce the desired effect. The mechanic s work beeomes easier and the ploughman's less toilsome when performed to their own musical accompaniment. Neither can it be cloubted that the peculiar music of sailors as they haul on the ropes of their ressel has its effect in lightening irksome labor. Our southern brethren will bear me out in the observation that negroes perform their appointed tasks with greater patience by reason of the inspiriting effect of their rollicking melodies. No festival ean be properly celebrated without music, and the pleasures of the board are infinitely brightened by the strains of an orchestra or lively song. 'To dance without music is to rob the exercise of all its zest, and in this connection one hits but to put one's fingers in one's ear's and watch a ball in progress to convert the ball-room for the nonce into a scene of Bacchanalian revelry or the most disturbed ward of an insane asylum. In times of war as well as in the piping times of peace music exerts its helpful iufluence on the mind, and the soldier goes forth to battle oblivious of all danger and eager for the fray.

At the battle of Quebec, April, 1\%60, the Scotch troops were retiring in the greatest disorder when the musicians were ordered to strike up their favorite airs. The flight was at once arrested and the soldiers pressed on to battle. Every one knows how during the civil war courage was inspired by the military music of the contending forces. Certain simple melodies of the Swiss mountaineers, commonly played on the Alpine horn and known as the ranz des vaches, so strongly affected Swiss soldiers as to cause them to desert and flee to their homes. So frequent and disastrous became such desertion that the airs were forbidden in the army under pain of death. 
It is well known too that by the sweet spell of music the pangs of death itself can be made to disappear. Fran\% Rocco, who, in the French war of 1 sot, was sentenced to death in Wurtemburg, played gaily on a jewsharp as he strode to execution. It is related that when death had laid his finger on the sensitive, restless and highly poetic ('hopin, and the composer was suffering violent pain, he summoned to his bedside his friend, the Countess Potocka, to assuage his death agony by her melodious voice. The heartbroken singer obeged the masterthe dying man came under her spell-he forgot his torment and fell asleep with a feeling of inmort gratitude to the wonderful soother.

Instances like the above might be multiplied indefinitely were I not afraid of becoming wearisome. But not only on man but upon the lower animals also does the power of music make itself felt. The camel in the desert and the horse on the field of battle go forth with greater courage and resolution to the music of drum and bugle. Lizards, rerpents, elephants and other animals become tame under its magic influence. Prisoners tell of rats, mice, spiders. \&c.. whose friendship has been gained through music, and the legend of the P'ed Piper of Hamelin is - too well known to be recalled to this andience:

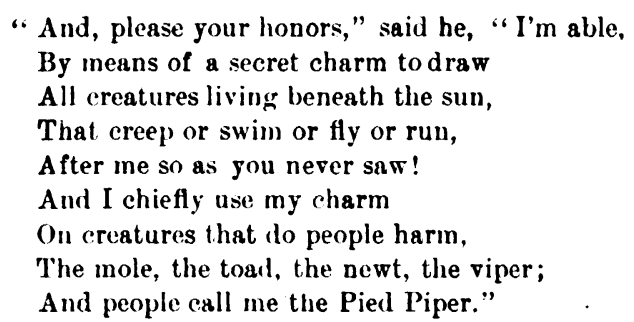

But the effect of nusid "1pon man varies much with the conetitutional temperament and degree of culture possessed by the individual. As a general rule savage tribes, to whom, as has been well said, music is calomel and quinine and a whole pharmacoparia, enjoy a rude music that would drive us to despair. From IIomer we learn of the love of the ancient Greeks for wild weird song. Of Peter the Great it is asserted that he could not tolerate French and Italian musie, and a still worse taste was displayed by louis $\mathrm{X} 1$. 
As to the precise manner in which music produces its wonderful effects it is difficult and indeed impossible to determine. There are so many factors in an analysis of music that it is out of the question to ascribe a definite value to each in any such estimate. Whether it be the rhythm, the time, the melody, or the harmony or what not, or all combined, that accomplishes the object matters little, however. If know that rhythm must ina ie a distinct utilitarian value in the work of the blacksmiths as, under the spreading chestmut tree or elsewhere, they ply their hammers in unison. Similarly, a college crew is soon mate to realize the resourees of rhythm, while it enters manifestly as an important factor in the old-fashioned threshing with hand flails. Again the time of a march of ten compels us to keep step, with the music on nights of torchlight processions and campaign finfaronnader.

Weber relates an amusing instance of the changefnl effects of tempo as applied to manual labor. It appears that a Londou: tailor noticed that his patriotic apprentices were fond of working. to the slow time of "God save the Queen," very much to thedetriment of his business. He therefore hit upon the crafty: expedient of prescribing a livelier air, aind at once obserred the quickening effect of the music upon their needles. Not long ago I read in one of our papers that a boss carpenter somewhere hereabouts invariably asked would-be workers under him if they whistled as they plied the plane or saw. If they replied in the affirmative, he bade them whistle their favorite air, when, in the event of a preference on their part for a slow tune, it was "all up" with them, while "Yankee Doodle" furnished an immediate passport to the bench. We all know the effect upon us of such music as the " Dead March in Saul;" and modern funeral mnsic, affording its luxury of woe in a hidden corner of the house, is often more thoroughly enjoyed by the mourners than the funeral sermon itself.

The effect of music varies much according to the medium used. While drum and bugle inspire courage, they may also give rise to sorrowful impressions. The celebrated æsthete Lemcke characterized musical instruments in the following manner: 'The flute is placid; the clarinet is sensuous; the hautboy is nervous; the violin resembles an emotional woman-it rejoices, sighs and weeps and makes its voice heard first, last and all the 
time. Earnest, melancholy even woesome is the violoncello; it becomes funny when it attempts a jest and represents man. The bass viol is quiet and dignified in its deportment; indisposed to any kind of frivolity, its utterance is important; powerful under excitement and full of solemn threat in anger. It represents the type of mature age. The strains of the harmonica fill the heart with a namcless longing; and nothing produces more profound emotion than the now swelling now melting tones of the colian harp with its weird unearthly effects. But king of all as regards its influence on the mind is the organ. It has a peculiar charm of its own whether in its softest or most thundering tones. 'Thus it happens that so many and such varied sensations may be evoked through its instrumentalityindeed, every emotion from the mildest to the most violent is susceptible of expression on the organ, and it stands unrivalled as an imitator of natural phenomena. It is related of the German organist Vogler that he was able to imitate so closely upon his instrument the effect of rain that the men in his audience instinctively put on their hats and the women spread their handkerchiefs over their bonnets; and so faithfully is he said to have produced upon his hearers the effect of thunder as to elicit on all sides the exclamation "Gott wenn es nur nicht einschlügt!" in intimation of a fear that lightning might strike the building. Remarkable as these performances were, it was reserved, I believe, for an American artist to so usurp the powers of electrical phenomena through the medium of his organ as to cause all the milk for miles around to turn sour.

The most powerful and most complete musical instrument is the human voice, so far as its effects upon one's fellow men are concerned. Nothing can so affect one's emotions as the immediate action of man's voice upon man, whether that influence be exerted by speech or song. There is something in the quality of the human voice itself that may rivet attention and enlist sympathy, or on the other hand be of a nature to distract and repel. How frequently indeed does it happen that even the lowcr animals will heed the voice of one man and be driven forth by another. How often too does it come to pass that the voice makes ample atonement for the poverty of a discourse, while on the other hand the most brilliant lecturer often fails to gain a hold upon an audience if his delivery be in quality totally 
disproportionate to the wealth of his ideas. It is safe to infer that the famous preachers of the world were all pleasant talkers, and that the traditional old lady who brought home the solitary word "Mesopotamia" as the only registered fact in memory after what she termed a "b-e-a-u-t-i-f-u-l" sermon, had been inveigled into the hopeless confusion of shadow with substance in her homely estimate of what constituted beauty in discourse by the mellifluous voice of her spiritual guide.

It follows then from all we have said that music must have a powerful effect upon the nervous svstem. and that asylums for the insane offer a natural sphere for its bencticial effects upon disease.

To the asylums of France is due the credit of having first introduced music as a regular feature in the course of treatment. At the hospital for the insane near Rouen, an attempt wats made early in its history to organize a band of music and chorus, and so successful did it prove that the good example was followed by numerous other institutions, not only in France, but elsewhere on the Continent. In more recent times a distinguished French scientist has attempted a new application of the theory of the transformation of mechanical movement into psychological and psychical movement, with a view to employing music as a means of curing or alleviating diseases of body and mind. $\mathrm{He}$ attempts an ingenious scientific explanation of the general influence of music on the development and functional play of the moral and intellectual faculties, and on the physiological state of individuals. This general influence may be decomposed into specific influences, and the following results are arrived at: There is, first, a music which acts specially on the intelligence and on the motor nerves; secondly, a music which acts specially on the nerves of sensibility and on the sentiments; thirdly, a music which acts all at once on the motor nerves and on the sensory nerves, on the intelligence and on the sentiments-this in general being the action which most frequently occurs. This enthusiast goes to the extent, even, of believing that he has discovered, between the effects of music and the nutrition of the nervous system, such analogies that the laws which regulate the one and the othe" might be formulated in the same terms. Nay, further, we might establish a method in hygiene, in medicine and the moral sphere, of profiting by these specific inflnences, 
above all in the treatment of mental nervous affections, making allowance, of course, for individual idiosyncrasies. In short, music is an agent at once psychical and therapentical, capable of performing a considerable part in the phenomena of life, and the employment of which is susceptible of application according to precise rules based upon scientitic principles.

Still higher ground has been taken in Sweden in an analysis of the music of the heart itself. Many a time have the sensitive chords of hearts attuned to sympathy vibrated beneath the touch of pity, and often made grind tempestuous music within the joyful breast. But all this belongs to the readers of poetry, and scarcely consists with cold scientific fact. And yet it is claimed that the heart has its own musie, and a melomaniac, a man named Rhuders, a Swedish physician, claims to have harmonized the gentle conceits of poetry with the dull records of physiology. He has noted down in the language of "crotchets and quavers" the beatings of the palpitating heart of a woman in one of the hospitals of Upsal. The composition is said to resemble a somewhat irregular waltz, d deux temps, and, as the chronicler gravely remarks, it constitutes one of the most remarkable pathological curiosities of the day. It is suggested that this may lead in time to the initiation of a new system of drawing-room pathology, and ladies may have occasion some day to call a Thomas or a Strauss to note down in chords the sonnds of their beating hearts, and enable them, swan-like, to fade in music.

And here I am forcibly reminded of the "Anatomist's Address to His Adored One," as having special bearing upon this heart music:

I list as thy heart and ascending aorta Their volumes of vulvular harmony pour,

And my soul from their inuscular music has caught a New life 'midst its derd anatomical lore.

Oh. rare is the sound of thy ventricles' throb In a systolic symphony measured ind slow,

When the auricles answer with rhythmical sob, As they murmur a melody wondrously low.

Oh, sweet is thy roice as it sighingly swells 'Neath the daintily quivering chordo rocales, Or rings in clear tones through the echoing celis Of the Antrum, th'Ethmoid and Sinus frontales. 
In America, some interesting experiments were conducted in one of New York (ity Lunatic Asylums, Randall's Island, eleven years ago, and the claim was made that several of the patients were greatly benefited. From the reports made at the time it appears that cantabile music had an effect similar to that which it exercises upon certain animals, the person being disposed to lie down and go to sleep under its influence. It does not appear, however, that this was anything more than a spasmodic attempt to introduce music into the institution as a systematic part of the moral treatment.

While my own enthusiasm as regards music does not exalt it into an agent pre se of cure in disease, I believe it to be decidedly beneficial in a variety of cases. My attention was first called to the value of music as mind medicine at the Uticas State Hospital by the persistent search on our premises by two villainous looking gentlemen from sunny ltaly for such eleemosynary nickels as might fall from grated windows in substantial recognition of a musical reminder from a badly demoralized hand-organ of the better fate that was in store for our unfortunate patients in the "Sweet Bye-and-Bye." Maddened myself by the dismal sereech of the instrument, I had the hardness of heart and temerity to drive the pestiferous players forth, and away they went in dudgeon, muttering Italian curses between their teeth. Later in the day one of the employés of the asylum chanced to see these men basking in the sun while munching their mid-day meal. He was recognized by the grimmer of the bandits, who at once arose, and opening a drawer in his hand-organ, displayed a large-sized revolver and a blood-thirsty knife. He eked out his broken English by violent gesture, and passing his lank fingers deftly across his throat, intimated with significant emphasis a lurking desire to shoot and behead the offending official who an hour ago had taken bread out of a hungry mouth, and declined with thanks to be told mechanically of the "land that is brighter than day." Full of alarm the employe aforesaid hastened to announce my impending assassination, and to afford me much-needed time to prepare for the "Father that lives over the way." I confess that the narration of the awesome incident somewhat alarmed me, and for some time thereafter I was on the alert by night and by day when out of doors. With the returning season of 
Italian street opera, my two friends appeared onc more. Then it was that I realized more than ever before how important a part discretion plays in valor, and how strong in my own case was that instinct which Dr. Bucke tells us shall not be accepted as a criterion of sanity. At once the hard-hearted despot of the previous season became

Generous as spring dews that bless the glad ground,

And courteous as monarch the morn he is crowned.

I insisted that the Italian artists should partake of the hospitalities of the house, and in the language of Cook's tourists' circulars, I "personally conducted" them. First they played in the exercising ground for disturbed women-when, by the bye, it became their turn to exhibit fear-and it was remarkable to witness the almost instantaneous effect of the simple music on the patients there assembled. These women became at once less boisterous, and were all evidently interested in and diverted by the impromptu entertainment. From this yard the distracting playere entered soine of the wards, and here again the salutary effect of music was made apparent, though it was amusing to see one of the men, evidently not realizing the precise character of the institution, pass round his hat from patient to patient in vain appeal for bounty. Largess was duly provided elsewhere, however; and I had thus demonstrated to my satisfaction, the fact that we possess in music a power over the insane that might be turned to good account by simple means, while, what to me personally was vastly more important, I had made my peace with a would-be assassin by the payment of a modest ransom. 'This was the beginning of a systematic use of music at the hospital, and soon led to the formation of an orchestra.

By advertising in the New York papers, and especially the great German daily, for musicians willing to act as attendants upon the insane, I was able to enroll an army of candidates, and pick out my men at a given rendezvous in the city. By this means it was not difficult to get together able-bodied young men, competent alike as attendants and members of an orchestra. The candidates had not been long enough in the country to become members of the union, and were glad to accept situations at ordinary rates of compensation. Attendants with musical ability were engaged in preference to others. One of 
the first departures was to substitute for the bell in the courtyard clanging the announcement of meals and the hours for quitting and resuming work, the melodions bugle calls of the army. On evenings of entertainment, and especially when the regular weekly dance is given, the musicians do much to enliven the audience and dancers and non-dancers alike. Again, concerts are given in different wards during the week, and especially in those in which eases of acute melancholia are received and cared for.

In this class of cases music gives promise of having a distinct value. It would not be true to allege instances of wonderful cure by music alone, such as may be found scattered here and there through the literature of mental medicine. There is always ample room in treatment of any kind for the argument post hor ergo propter hor, and always a disposition to ignore the awkward question, Would the patient have recovered, thanks to the healing forces of nature, without your interference?

The interdependence of treatment and causation goes without saying in all diseases; and as it is difficult or impossible to assign a single factor as having produced a certain morbid result, because disease, and especially insanity, is usually due to a conspiracy of conditions, so likewise in treating that disorder credit must not be given in successful medication to one thing only, but to all the resources of our art combined that may have been brought to bear in a given case. Thus, it is impossible to measure the precise value of music in our armamentarium. It cannot be placed on a par with drugs in this respect, and one must be content to speak of its therapentic value in mere general terms. It were as reasonable to expect a definite statement as to the value of theatrical entertainments, of dances, of athletic sports, of reading, of looking at pictures that please the eye, and of the thousand and one things that comprise what is generally known as moral treatment in hospitals for the insane, and which affect the body favorably through the mind and nervous system. We do know that for the moment attention is diverted from self to the orchestra, and that in so far morbid self-introspection can be checked. We know that through the nervous system the heart beats faster and the circulation is quickened, and that in so far the functions of the body are stimulated to greater activity. Similarly, 
respiratory movement may be accelerated and the blood subjected to follow aerration. In these and other ways it mily be claimed that music is helpful in the treatment of insanity, and one is inclined to bespeak for it greater consideration, as one of the readily available appurtenances of an asylum, than has heretofore bee: vonchsafed by the craft. Our own experience has been most gratifying in exciting interest and allaying irritation. 'The patients are evidently infuenced for good in the majority of cases, and take an intelligent interest in the ward concerts provided for them. Inmates of other wards beg the privilege of going to the one in which the orchestria is performing, and many express gratitude for the relief that the music atfords them.

Cases recorded in the literature of psychiatry are not few where the cure by music has bordered on the miraculous. In nearly all of them there is an undercurrent of sensationalism and a flavor of romance such as to suggest that the enthusiast has attained his end by fabricating facts where stern clinical reality failed to supply them in sufficient measure to suit his fancy. Ancient history furnishes a large share of these cases.

"And it came to pass when the evil spirit from God was upon Saul, that David took a harp and played with his hand; so Saul was refreshed and was well, and the evil spirit departed from him."

Of Pythagoras, who was the father of music as a mathematical science, it is related that he not only loved music, but. had recourse to its powers to relieve mental strain in himself and his followers, as well as to encourage the reflective mood. Throngh music he induced in himself and his pupils the loftiest perceptions, curbed all froward passion and encouraged virtuous resolve. Indeed, he referred the origin of melody to the gambols of the spheres. "Next to theology," said the mirth-loving Luther, "I give the highest place to music, for thereby anger is forgotten; the devil, also melancholy and many tribulations and evil thoughts are driven away."

It is best to refrain from detailed reference here to the more or less apocryphal instances of relicf afforded in the cases of such personages as Haroun al Raschid, Philip of Spain, the bandits sent to capture Alessandro Stradella, and the Hungarian count who was charmed into recovery by Mara. Certain it is, 
that no such sensational cures have been brought about in our own bospital, and we are indisposed to magnify the effect of music per se as a curative agent. Yet our experience accords with that of other observers who would place music in that group of natural recreative forces which are active in every healthy life, and which operate against the morbid weakness of any part by increasing the vigor of the whole.

it is to be borne in mind that there is constantly occurring in the organism an appropriation of external impressions by the hrain which goes on unconsciously. "As the various, organs of the body," says Mandsley,* "obtain from the blood the material suit:able to their nourishment and assimilate it, so the organ of the mind uneonscionsly appropriates, through the inlets of the renses, the intluenees of its surroundings." And thus the nature of the mind may be permanently affected by these unconscious processes. The varying manner in which music affects some persons, producing a lively feeling of immediate pleasure, calming mental agitation and exalting the mental tone, and thereby indireetly much affecting mental activity, is adduced by Maudsley as an excellent example of a marked effect upon the psychical tone by physical agency. Indeel, he goes further in his recognition of the corporeal nature of the process, holding that such sentiments as the love of wife and children are not so much definite emotions as a general tone of feeling resulting from certain relations in life, and that they represent a mental state in which ideas in harmony with a given tone of mind will l:c attended with a pleasant emotion and discordant idleas with a bainful emotion, precisely as harmony in music produces pleaswre and discord prin. Resolved into simple terms, the proposition is this: the effect of music has much to do with the 1ome of mind engendered by it. And that the mental tone of an individual has much to do with his power of resistance when disease orertakes him, groes without saying. Faith-cures and other humbugs furnish ample evidence of this fact.

In briefly summarizing the results of experience in concluding this desultory compilation, I would say that we have in music an element of moral treatment that we cannot afford to neglect. It is within the reach of all hospitals for the insane to provide systematic musical entertainments for its patients. Some,

\footnotetext{
- The Physiology of Mind. p. 2 .
} 
despising the day of small things, may not think the swift hard precision of a mechanical piano, with its arrangements of musichall songe, such as "Down Went McGinty," or an Indian brass band at Niagara Falls, is music. Yet the admiration for then is the same emotion as is evoked, though with more critical reservations, from the cultured at a Thomas concert. One can forgive the ear splitting music of the street when one sees as we have seen from these windows the marching and dancing of the children. Similarly, one can adapt the music of the hospital to the varying tastes and moods of those for whose benefit it is discoursed, and contribute, I :m convinced, in no small degree to the well-being and recovery of our patients.

Music, all powerful o er the human mind, Can still each mental storm, each tumult calm, Soothe anxious cure on sleepless couch reclined And e'en fierce anger's furious rage disarm.

[Bibliography.-Bratelel\%, (G. L.): The Medical Uses of Mugic, N. Eng. M. Monthly: :Newtown, Conn., 1882-3, ii, 214-216. Brierre-de-Boixmont, (A. J. F.): De 1s musique dans les asiles d'aliénés et des concerts de la Senavra et de Quatre-Mares. Union Méd., Paris, 1860, 2 \&, vii, 337-34t. Jennings, (0.): Music as a Therapeutic Agent, Lancet, Lond., 1880, 1i, 794. Laurent, (A.): Quelques observations reiatives à l'influence qu 'exerce la musique sur les aliénés, A nn. Méd. Psych., Par., 1860, 35. vi. 331-366. Luzinsky, (A. M.): Die Musik in der Medizin, Ally. Wien. Med. Ztg., 1882, xxvii, 271, 283. Maudsley (H.): The Physiologv of Mind, MacMillan \& Co., Lond., 1876, pp. 24 et seq. Music as Mind Medicine. Virz. M. Monthly, Richmond 1877-8, iv, 920-823. Whittaker, (J. T.) : Music as a Medicine; Clinic, Cincin., 18.4, vi, 289-294.] 